臨 床ノ一 一

\section{䔬便内寄生虫卵検査における 表面活性剂の応用について}

渡辺 仙* 武富和夫* 佐藤篤男*

家畜の衛生および診療上寄生虫病の重要性に鑑み, 消 化管内寄生虫の早期かつ正確な発見のため, 糞便検查法 の改良，創案が引き続き試みられてきている.

食品あるいは食器などの清洗に表面活性剤を使用する ことは, 最近ますます普及し, 野菜類からの回虫卵洗除 の効果に関する成績は予防衛生研究所からも発表2)さ れまた東ら1)は牛の肝蛭虫泗の検出に本剤がすぐれた 効果のあることを報告している.

私たちは大の消化管寄生虫の検診のため, 粪便検査上 本剤応用の価値について研究した．以下その要旨を報告 する。

\section{実験材料および方法}

1. 材料 本研究に用いた表面活性剤はワンダフルK

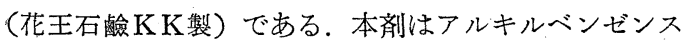
ルホン酸ナトリウムを主凧とした製品で，実験には本阂 の $0.5 \%$ 水溶液（以下ワンK液と略称）を使用した。

供試資便は日本獣医畜産大学臨床学教室の実験犬およ び外来患犬ならびに附近の家庭に飼育されている犬，計 25頭を材料とした。

\section{2. 方法}

1）単純遠沈法 集卵に際しワン $\mathrm{K}$ 液と水との比較試 験を行なった。

すなわち糞便を 2 本の試験管に各 $1 \mathrm{~g}$ ずつとり, 一方 にはワンK液を, 他方には水を, それぞれ $5 \mathrm{cc}$ ずつ入 れ, 攪找混和し, 2,000 回転, 3 分間遠沈した後, 上清 をすて沈渣を混和し, 次いで毛細ピペットで吸引し，ス ライド上にその 1 滴を滴下して, $18 \times 18 \mathrm{~mm}$ カバーグラ スをのせ鏡検した，同様のスライド 3 枚を作成し，鏡検 して，その卵の平均数をその犬の虫卵数とした。

2) 矢尾板変法（ワンダフルK併用法） $10 \%$ アンチ ホルミンェーテル法 (矢尾板法)を行なうにあたり, 賞 便の溶解希釈にワンK液を使用し，別に同一糞便につき 溶解希釈に水を使用し矢尾板法(原法)を実施し対照とし た.

1 塊の䆏便の両端ならびそ中心部を混合し, 各 $1 \mathrm{~g}$ を 供試便と対照便とした。

供試便 $1 \mathrm{~g}$ を中試験管にとり，ワンK液 4ccを加光， ガラス棒で賴塊を攪拌溶解した後, ガーゼ 1 枚を通して 遠沈管に沪過し, その沪液を 2,000 回転, 3 分間遠沈し た.

* 日本獣医畜産大学内科学教室
遠心分離後，上清をすて沈椬に10\%アンチホルミン溶 液 2cctおよびェーテル 2ccを加えよく振盪攪找し, 再度 遠沈した。上清 3 層をすて, 沈渣を混和し, 毛細ピペッ トで吸引し，スライドグラス上に 1 滴ずつ 2 カ所に滴下 し, 各18×18mmのカバーグラスをのせたものを 3 枚作 成鏡検し，その虫卵の平均数を記録にとどめた。

なお，対照便は $1 \mathrm{~g}$ を中試験管にとり，井戸水 $4 \mathrm{cc}$ 加え以下供試便と同様実施した。

\section{実 験 成 績}

試験実施前に, 供試便中の虫卵数の程度を知るため, あらかじめ簡易塗抹標本で鏡検して虫畉の有無, 程度の 概要を調べ供試犬を選定した。ささらに単純遠沈法による 調查では, 鈎虫の寄生犬が多く, 鞭虫のそれは少なかっ た (第 1 表).

第 1 表 単純遠沈法による検出虫畉数

\begin{tabular}{|c|c|c|c|c|}
\hline \multirow{2}{*}{$\begin{array}{c}\text { 使 用 品 名 } \\
\text { 虫畉名号 }\end{array}$} & \multirow{2}{*}{$\frac{\text { 井 }}{\text { 鈎 虫 }}$} & \multirow{2}{*}{$\underbrace{\text { 水 }}_{\text {鞭 虫 }}$} & \multicolumn{2}{|c|}{$0.5 \%$ } \\
\hline & & & 鈎 虫 & 鞭 虫 \\
\hline 1 & 1 & - & 5 & - \\
\hline 2 & 3 & - & 3 & - \\
\hline 3 & 11 & 6 & 9 & 5 \\
\hline 4 & 5 & 15 & 7 & 19 \\
\hline 5 & 3 & - & 9 & - \\
\hline 6 & 2 & - & 3 & - \\
\hline 7 & 4 & - & 12 & - \\
\hline 8 & 3 & 一 & 5 & - \\
\hline 9 & 1 & - & 3 & - \\
\hline 10 & 2 & 2 & 4 & 3 \\
\hline 計 & 35 & 23 & 60 & 27 \\
\hline
\end{tabular}

虫卵の検出率はワンK液使用のほうがはるかに良好 で, 井水使用のほらが劣っていた。 すなわち10例の平均 に沶いて, ワンK液使用と井水使用との虫卵検出数は, 鈎 虫卵 $60: 35$, 鞭虫卵 $27: 23$ のごとく鈎虫莭は約 1.7 倍で, 鞭虫畉は 4 個の差であった。 ただし10例中各 1 例が井水 使用のほうに多く検出されている。

詳記すれば，ワンK液を使用してよい結果の出たもの は鈎虫卵 8 例 $(80 \%)$, 鞭虫卵 2 例 $(67 \%)$, 同じ結果の出 たもの鈎虫畉 1 例 $(10 \%)$, 劣った結果の出たもの鈎虫卵 1 例 $(10 \%)$, 鞭虫卵 1 例 $(33 \%)$ であった(第 2 表).

矢尾板変法（ワンK液併用）に和讨る虫卵検出率は， 17例の平均に扮いて, 対照 (矢尾板原法) 飞比乙鈎虫卵 $907: 547$, 鞭虫卵201:129, 回虫卵 $28: 15$ であって, ワ ンK液使用のほうがはるかによい結果を得た(第 3 表).

すなわちワンK液使用でよい結果の出たものは鈎虫卵 11 例 $(73 \%)$, 鞭虫卵 5 例 $(50 \%)$, 回虫卵 2 例 $(100 \%)$, 同じ結果の出たもの鈎虫卵 2 例 $(13 \%)$, 鞭虫卵 2 例 $(20$ $\%)$, 劣った結果の出たもの鈎虫卵 2 例 $(13 \%)$, 鞭虫卵 3 例 $(30 \%)$ であった（第 4 表）.

日獣会誌 14 (1961) 
第 2 表 単純遠沈法との比較成績

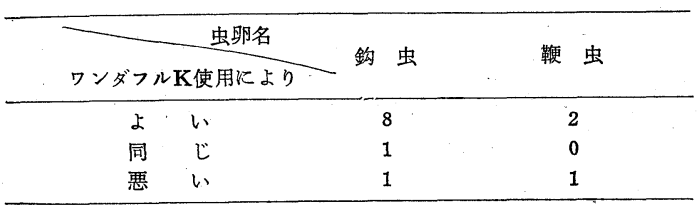

第 3 表 矢尾板変法(ワンダフルK併用法)による 検出虫卵数

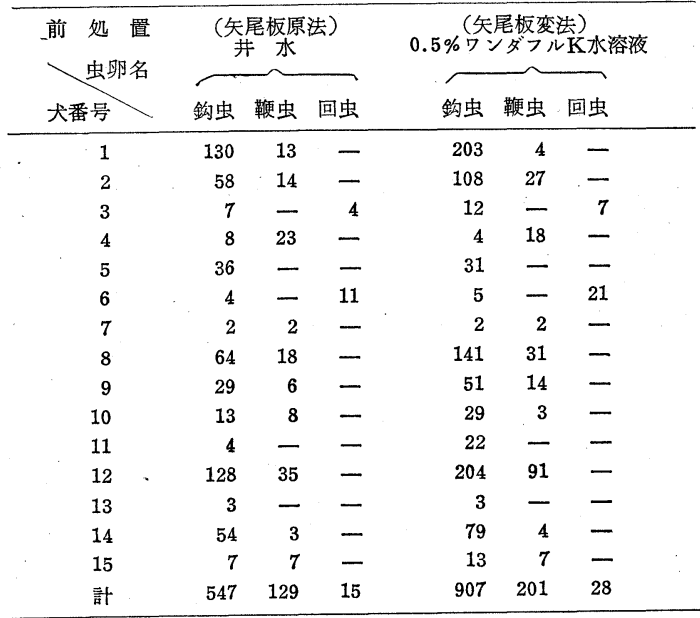

第 4 表 矢尾板原法拈よび同変法との比較成績

\begin{tabular}{|c|c|c|c|c|}
\hline ワンダフ & 飞使用により & 鈎 虫 & 鞭 虫 & 回 虫 \\
\hline L & $w$ & 11 & 5 & 2 \\
\hline 同 & ビ & 2 & 2 & - \\
\hline 悪 & w & 2 & 3 & - \\
\hline
\end{tabular}

なお，粪便をガーゼで汇過した際に，虫卵が食片残渣 およびガーゼに附着抑留されているか否かを実証するた めに再洗試験を行なった。すすなわちワンK液10ccをシャ ーレ2 個に入れ，1個のほうで供試便使用 (ワンK液使 用) のガーゼ（食片残渣とも）を，他の 1 個で対照便使 用 (井水使用) のガーゼをそれぞれ上下, 左右に 10 回 振り洗いし，その洗い水を遠沈管にとり，2,000 回転3 分間遠沈した．沈渣をよく混和し，毛細ピペットに吸引 し，スライドグラス上に 1 滴ずつ 2 カ所に滴下し，各 18 $\times 18 \mathrm{~mm}$ カバーグラスをのせたものを 3 枚作成鏡検し， その虫卵の平均数を虫卵数とした。

またワンK液のかわりに 2 個のシャーレに水を入れて ワンK液の場合と同様に 再洗試験を行なった。そ結 果, 糞便沪過の際にワンK液を使用したもののほうが沪 過ガーゼの虫卵抑留数が少なかった（第 5 表）.

なお，実験中に打いて虫卵の破壊像は見られなかっ た.

\section{総括执よび結 論}

野菜などの洗剤として市販されている表面活性剤ワン
第 5 表 再洗により収集された虫卵数

\begin{tabular}{|c|c|c|c|}
\hline 犬番号 & $\mathrm{T}_{\text {方 法 }}$ 鈎虫卵 & $\begin{array}{l}\text { 矢尾板原法) } \\
\text { 开 }\end{array}$ & $\begin{array}{c}\text { (矢尾板変法) } \\
0.5 \% \text { V }\end{array}$ \\
\hline 1 & $\begin{array}{l}\text { 矢尾板法 } \\
\text { ワダフルで洗ったすの }\end{array}$ & $\begin{array}{r}20 \\
8\end{array}$ & $\begin{array}{r}43 \\
5\end{array}$ \\
\hline 2 & 矢尾板法 & $\begin{array}{l}62 \\
32\end{array}$ & $\begin{array}{l}71 \\
19\end{array}$ \\
\hline
\end{tabular}

ダフルK液を粪便検査，すなわち単純遠沈法および矢尾 板法に応用して虫卵検出を試みだ結果を要約するとおお むね次のようになる。

1. 鈎虫卵に打いては単純遠沈法および矢尾板変法に ワンダフルKを使用した場合，対照便の平均約 1.7 倍の 虫卵数を検出した。鞭虫卵では単純遠沈法で10例の検出 卵，総数 27 (ワンK使用）：23（対照）で 4 個の差，ま た矢尾板法で15例の検出卵，総数 201 (ワンK使用) $: 129$ (対照)で対照便より約1.7倍の虫卵数が検出された.

2. ワンダフルK使用により鈎虫卵および回虫卵の検 出はよい結果を得たが，鞭虫卵の検出はわずかによい結 果にとどまった（第 2 表および第 4 表）.

3. 汇過ガーゼに抑留される蝍数はワンダフルK使 用の場合きわめて少なく，換言すれば虫畉検出率の高く なることが証明された。

4. 矢尾板法および単純遠沈法でワン $\mathrm{K}$ 液使用例の鞭虫 畉検出率が鈎虫卵拉よび回虫卵のそれに比べて劣ってい る理由については不明であるが，鞭虫卵はその表面粘性 に乏しく，あえてワンダフルKの使用を要せず水をもっ て容易に洗い落されるためではないかと想像された.

な拉，ワンダフルKは芳香を有し，かつ実験器具の使 用後の清洗の助けとなることは附帯的利益である. 単純 遠沈法と矢尾板変法とはその結果に执いてほぼ同一であ る.したがって実施簡易な前方法が実用上よいように見 えるが，本法によっては残渣中霬便細片，とくに無定形 物質(脂肪類)，粘液塊などがやや多量に残存するため卵 子の識別は矢尾板変法に比してやや困難であるといら次 点がある.

肉食獣の検便には矢尾板変法が最も精度が高いが, 草 食獣に扎いてはむしろ簡易な単純遠沈法がよいと考えら れる.

稿を終るにあたり，本研究にご指導並びにご校閲を睗 わった本学本井正次教授化謝意を表します。

$$
\text { 参考文 献 }
$$

1）東 胤弘, 外 : 日獣会誌, 11,535 (1958)。 2) 予研総般 : 第 57 , 58号 (1958).

\section{犬の12指腸虫症の新薬}

Bephenium hydroxynaphthoate は犬の Ancylostoma caninum \& Uncinaria stenocephala 飞対してすぐれた 駆虫作用を有する。駆虫試験では $100 \mathrm{mg}$ を 1 回投与する よりる $50 \mathrm{mg}$ を朝と晚、没与する方がより效果的であっ た. (D.A. Rawes : Vet. Rec. 73, 390, 1961) 